question, unable to seize a morsel of food lying in the angle formed by the glass front and bottom of the tank, "raised himself into a slanting posture, the head inclined upwards and the under surface of the body towards the food," and, by waving his fins, caused a current in the water which lifted the food straight to his mouth. Mr. Romanes adds that this observation is practically worthless "from the observer having neglected to repeat the conditions in order to show that the movements of the fish were not, in their adaptation to these circumstances, purely accidental."

I quite agree with Mr. Romanes that such observations should be tested in every possible way, and I should have been only too glad to repeat the conditions of this and other observations had I been able to do so. The fact is, however, that as neither the directors nor the curator of the Manchester Aquarium were willing to call in the aid of those extra attractions which you London people seem to have successfully employed in the case of the Westminster institution, the Manchester Aquarium came to an untimely end, and thus my observations were cut short. There are, however, two comments which I should like to make On p. 351 of "Animal Intelligence" (the coincidence in the numbering of the respective pages may help the reader's memory), Mr. Romanes quotes a story by Mr. J. S. Hutchinson concerning a Polar bear at the "Zoo." A bun was thrown into a pond, and fell "at the angle" beyond the reach of the bear. The animal thereupon "commenced stirring the water with its paw, so that it established a sort of rotatory current which eventually brought the bun within reach." This story was communicated to Mr. Romanes privately, and my skate story was published in your columns four years before $\mathrm{Mr}$. Romanes published his book (see NATURE, vol. xix. p. 160). No repetition of the conditions is mentioned in the case of the bear, yet Mr. Romanes speaks of the story as " a most remarkable observation." In justice to Mr. Romanes I must add that he appears to accept the bear story as a proof of intelligence in that animal because it corroborates a similar story communicated to $\mathrm{Mr}$. Darwin by another observer. I feel, however, that I have a right to back my skate against either of the bears named, for the following reasons. Had I repeated the conditions in the case of the skate with precisely the same result, it would have appeared as though the skate acted in obedience to inherited babit, or instinct, and even the similar conduct of the bears suggests this inference in their case. On the other hand, had a second trial with the skate failed, it would not have been proved that the first case was accidental, and therefore not the result of a "happy thought" on the part of the skate; for it might still have been contended that the skate, like a man, might display presence of mind on one occasion, and not on another, and the chief interest of the incident lies in the assumed spontaneity of the action. Finally, if $\mathrm{Mr}$. Romanes will reflect upon the attitude of the fish as described in my narrative, I think he will see that the movements could not be "purely accidental." For, from the position of the skate's eyes, it follows that, when in the slanting posture described, he could no longer see the food. Yet he opened his mouth and adroitly caught it, the waving of the fins and the opening of the mouth being necessarily rapidly consecutive actions. This fact seems to me to show that he expected the food to rise in the way in which it did rise. F. J. FARADAY

Manchester, January 21

Your correspondent seems to think that I had some particular spite against his skate, and quotes my indulgence to a bear as proof of inconsistency. But the two cases are very different. Even apart from the unconscious corroboration to which he alludes (and which as evidence of a fact I consider better than even verification by the same observer), we must remember that the stirring of water for a long time in the same direction with its paw is not quite so habitual an action on the part of a bear as is the ordiuary swimming movement $c n$ the part of a skate. As for any difficulty which the skate $m$ ty have had in seeing the food approach its mouth, surely the fact of its opening its mouth when the food was near enough to grasp is no better evidence of design than of accident. In either case, under the conditions, and more especially the "attitude," described, the seizure of the food at the proper moment can only be ascribed to the sense of smell, which in the skate is so highly developed. Lastly, why does your correspondent begin by saying that verification would have been desirable, and end by arguing that it would have been of no use? Even if the experiment had failed on repetition, he says, his inference would not thereby have been negatived. If this is so, assuredly there would have been no object in repeating the conditions. I once told a terrier to fetch me the ace of hearts from a pack of cards, and he did it. I happened previously to have known that the ace of hearts was the top card. Suppose I had repeated the experiment fifty times, and the dog had every time brought the wrong card, should I have been justified in attributing the first success to a "happy thought" ?

GEORGE J. ROMANES

\section{The Storm of January 26}

I SEND you inclosed particulars of the great storm of January 26 and 27 as observed at Newport, opposite Dundee. Another observer six miles to the north-east of Newport took readings which corresponded almost exactly with those at Newport for the fall, but were thirly to forty minutes later for the rise. They were as follows, being reduced and corrected :-

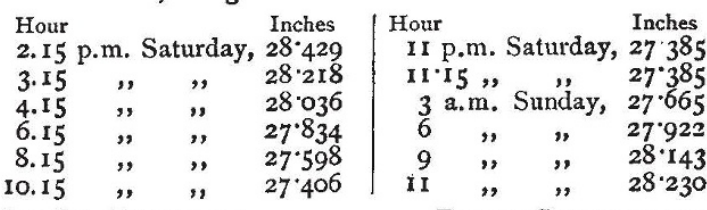

Dundee, January 30

David CUNNINGHaM

\section{Ozone at Sea}

DURING my voyage hither from London in the Maranoa, viâ the Canal, and calling at Malta, Aden, and Colombo, I was surprised at the low values for ozone as registered by Moffat's tests, which I pinned to the "uprights" in Stevenson's thermometer screen. I tried periods of exposure varying from half an hour to twenty-four hours, and the highest value noted was but 5.6 for eight hours (scale o to 10). The test papers, however, were always tinted, more or less, sometimes to $3^{\circ} \circ$ in half an hour, whereas tests exposed at the same time and examined when eight hours had elapsed, only gave $4^{\circ} 6$. At Ben Nevis and Fort William, and in the moorlands of Staffordshire I have recorded far higher ozone values than at sea under the same force of wind and like periods of exposure. From my long experience of these tests I cannot consider them satisfactory ; but in the absence of a more reliable method I would strongly suggest that they would give results more intercomparable if aniformly exposed for an agreed hourly period, especially at the various land stations.

Adelaide, South Australia, December 22, I883

\section{Meteor}

AT 9.55 p.m. on Sunday, January 27, I saw a meteor start from a point in Taurus, near to Saturn, and fall vertically a distance of $20^{\circ}$, and then burst with a brilliant flasb, giving off several colours that almost instantaneously died away. The meteor was visible about three seconds, and increased greatly in brightness from the time first seen until it burst. It was the most brilliant meteor I ever saw, and its greatest brightness much exceeded that of Venus.

Museum, Sheffield, February 5

\section{Ravens in the United States}

OUR Natural Histories say Ravens are common all over the United States, but I have never met any one who was aware of having ever seen one. Are they common in Westchester County, near the Hudson, and confounded with crows?

New York, January II

ManhatTan

\section{Unconscious Bias in Walking}

THE thought has occurred to me that "unconscious bias in walking " may be the result of inequality in the length of the lower limbs caused by the manner in which young children are carried. Each person appears to nurse solely on one arm; I think the right is more frequently employed. I have noticed when a child is held in the arm the side which is nearer the nurse appears to be in a somewhat cramped and unnatural position, the leg more or less bent, while the outer side is comparatively straight and free. Would not this, while preventing the full play of the muscles of the inner leg, tend to arrest to some extent its 